\title{
DETERMINATION OF AMMONIUM CONCENTRATION IN POST-PROCESS WATERS FROM UNDERGROUND COAL GASIFICATION
}

\author{
OZNACZANIE JONÓW AMONU W WODACH \\ Z PROCESU PODZIEMNEGO ZGAZOWANIA WĘGLA
}

\begin{abstract}
A flow injection analysis method for spectrophotometric determination of ammonium in waters produced during underground coal gasification (UCG) of lignite and hard coal was described. The analysis of UCG water samples is very difficult because of their very complicated matrix and colour. Due to a huge content of organic and inorganic substances and intensive colour of samples (sometimes yellow, quite often dark brown or even black), most analytical methods are not suitable for practical application. Flow injection analysis (FIA) is based on diffusion of ammonia through a hydrophobic gas permeable membrane from an alkaline solution stream into an acid-base indicator solution stream. Diffused ammonia causes a colour change of indicator solution, and ammonia is subsequently quantified spectrophotometrically at $590 \mathrm{~nm}$ wavelength. The reliability of the results provided by applied method was evaluated by checking validation parameters like accuracy and precision. Accuracy was evaluated by recovery studies using multiple standard addition method. Precision as repeatability was expressed as a coefficient of variation (CV).
\end{abstract}

Keywords: ammonium, flow injection analysis, gas-diffusion, underground coal gasification, waters from underground coal gasification

\section{Introduction}

The gasification of solid fuels is relatively well known and applied for several decades. Nowadays the coal gasification process is used to obtain synthesis gas for chemical industry and for production of a liquid motor fuel and a substitute natural gas. The possibility of combine coal gasification with electricity generation has recently caused considerable interest [1]. Gasification is a chemical process by which carbonaceous materials like coal or petroleum coke are converted at elevated temperature to a synthesis gas by means of partial oxidation with appropriate gasification agent (e.g. air, oxygen, steam or their mixture). The composition of gas discharged to the surface depends on the process technology, but always main products are carbon oxide and hydrogen [2,3]. Technology of coal gasification offers many environmental benefits [4], but there might also appear a risk of groundwater contamination with UCG (underground coal gasification) by-products [5]. The process and

\footnotetext{
${ }^{1}$ Central Mining Institute, pl. Gwarków 1, 40-166 Katowice, Poland, phone +48 322592852 , fax +48 322592273

*Corresponding author: mcykowska@gig.eu
} 
post-process waters which are the result of condensed steam, contain a wide range of organic and inorganic environmental hazardous substances. The characteristics of some physicochemical parameters of exemplary samples of post-UCG waters are presented in literature [2]. Samples of water produced during underground coal gasification of hard coal and lignite have a specific and a very difficult matrix and most analytical methods are not suitable for practical application.

Determination of ammonium by flow injection analysis with gaseous diffusion (FIA-GD) and spectrophotometric detection allows avoid matrix problems, therefore it became very popular among different FIA methods [6, 7]. However, many other flow systems for determination of ammonium with different kinds of detection [8-12] or flow systems coupled with other methods are also presented in literature [13, 14]. FIA-GD is a technique based on injection of a liquid sample volume into a moving non-segmented carrier stream. The injected sample forms a zone that disperses on its further way of analysis and then merges with alkaline solution stream (reagent 1). At the time all dissolved ammonium is converted into gaseous ammonium and then it is transferred throughout hydrophobic gas permeable membrane to acid-based indicator stream (reagent 2). The diffused ammonia changes the $\mathrm{pH}$ value of reagent 2 and, consequently, changes its colour, which is constantly monitored by spectrophotometer [6, 7]. The coupling of flow injection technique and gaseous diffusion technique (FIA-GD) is proposed for reliable and selective determination of gaseous compounds, especially ammonium, even in coloured aqueous samples with complex and difficult matrix.

In this paper ammonium was determined by gas-diffusion flow injection analysis. The aim of this work was to verify the applicability of FIA-GD method for determination of ammonium in heavily contaminated water samples from UCG process.

\section{Experimental}

\section{Apparatus}

A commercial flow injection system (FIAmodula, MLE-Medizin- und Labortechnik Engineering, Germany) was employed in this work. The FIA system was composed of the following elements: analysis module (FIAmodula), auto sampler (FIAsampler) and control software (FIAcontrol).

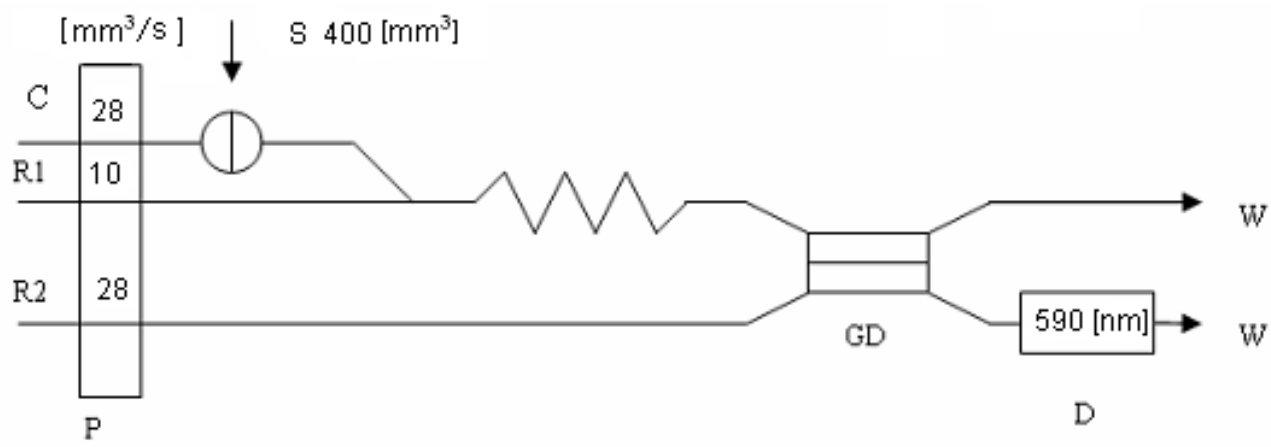

Fig. 1. Schematic diagram of the FIA manifold for determination of ammonium, $\mathrm{S}$ - sample; P - peristaltic pump; C - carrier; R1-R2 - reagents; GD - gaseous diffusion unit; D - detector; W - wastes 
The analysis module was composed of one peristaltic pump, $0.8 \mathrm{~mm}$ connecting tubes, injection valve with $400 \mathrm{~mm}^{3}$ sample loop, gaseous diffusion unit and spectrophotometric detector with pluggable $590 \mathrm{~nm}$ interference filter. The flow diagram is showed in Figure 1.

\section{Reagent solutions and carrier solution}

All reagent solutions were prepared using analytical grade quality reagents and deionised water (electrolytic conductivity less than $0.1 \mu \mathrm{S} / \mathrm{cm}$ ), degassed with helium before use. Carrier solution was deionised water. Dry indicator mixture was composed of bromocresol purple (Avantor Performance Materials), bromothymol blue (Avantor Performance Materials), cresol red (Avantor Performance Materials) and potassium chloride (Merck) in the weight ratio 4:2:1:18. Indicator stock solution was prepared by dissolving $1.25 \mathrm{~g}$ dry indicator mixture in $12 \mathrm{~cm}^{3}$ 1-propanol (Avantor Performance Materials) and in $12 \mathrm{~cm}^{3} 0.01 \mathrm{~mol} / \mathrm{dm}^{3} \mathrm{NaOH}$ (Avantor Performance Materials) and thereafter by dilution to $250 \mathrm{~cm}^{3}$ with deionised water. A mixture of $20 \mathrm{~cm}^{3}$ indicator stock solution and $5 \mathrm{~cm}^{3}$ solution of $0.01 \mathrm{~mol} / \mathrm{dm}^{3}$ sodium hydroxide was diluted to $500 \mathrm{~cm}^{3}$ with deionised water to make working indicator solution used as reagent 2 (R2 in Fig. 1). Before analysis, working indicator solution was stabilized in a dark place for a minimum two hours and then its absorbance was adjusted to the appropriate value falling within the range (0.50-0.55) a.u. (absorbation units) at $590 \mathrm{~nm}$ wavelength, by dropwise addition of $\mathrm{NaOH}$ or $\mathrm{HCl}$ (Avantor Performance Materials) diluted solution. Reagent 1 (R1 in Fig. 1) was prepared by dissolving $15.4 \mathrm{~g}$ EDTA (Avantor Performance Materials) and $6.4 \mathrm{~g}$ boric acid (Avantor Performance Materials) in $250 \mathrm{~cm}^{3} 1 \mathrm{~mol} / \mathrm{dm}^{3} \mathrm{NaOH}$ and thereafter making up to volume $500 \mathrm{~cm}^{3}$ with deionised water. All solutions were degassed prior to use by filtration (0.45 $\mu \mathrm{m}$ membrane filters, Merck-Millipore) under reduced pressure.

\section{Standard solutions}

A stock standard solution with certified content of $1000 \mathrm{mg} / \mathrm{dm}^{3} \mathrm{NH}_{4}{ }^{+}$(AccuStandard) was used to prepare working standard solutions for calibration. The other ammonium stock standard solution (used in the standard addition studies) was prepared by dissolving $2.9650 \mathrm{~g}$ ammonium chloride (Merck) (dried to constant mass at $105^{\circ} \mathrm{C}$ ) in $1000 \mathrm{~cm}^{3}$ deionised water. Working standard solutions were prepared immediately prior to analysis by dilution of appropriate stock solutions with deionised water.

\section{Samples}

Several water samples from underground coal gasification processes were under test. Five samples among thirty three tested samples were selected to study recovery by multiple standard addition method. Four samples (A, B, C and D) were carried out in the course of the UCG experimental simulations performed in the surface reactor (ex situ). Additionally, one more sample (E) was carried out in the experimental mine in real underground condition (in situ). What is more, five series of samples were under precision test $(\mathrm{F}, \mathrm{G}, \mathrm{H}$, I and J). These samples were collected during UCG different processes at regular time intervals of 12 or 24 hours. Information about time of collecting samples, kind and origin of raw coals that were subject to UCG process and selected physicochemical parameters of UCG process waters are characterized in Table 1.

In order to remove coal tars and other undissolved residues, all samples were filtered under reduced pressure through $0.45 \mu \mathrm{m}$ membrane filter (Merck-Millipore). After 
filtration, each sample was preserved by acidification by concentrated sulphuric acid (Merck) to reduce $\mathrm{pH}$ value below 2 . Samples were stored at $4^{\circ} \mathrm{C}$ until analysed.

\section{Procedure}

A water sample with ammonium content is aspirated by autosampler (pump from a glass cup into the $400 \mathrm{~mm}^{3}$ - volume sample loop). That well-defined portion of sample solution is injected into a continuous carrier stream of water and then it is mixed in reaction coil with continuous stream of reagent 1 . All dissolved ammonium ions are converted to gaseous ammonia due to strong alkaline $\mathrm{pH}$ value of reagent 1 . Generated ammonia is transferred through hydrophobic gas permeable membrane to a stream of reagent 2 that contains $\mathrm{pH}$ indicator, while residual of the sample is directed to the waste reservoir. In this way ammonia is transferred to a new matrix (matrix of reagent 2 solution), what significantly diminishes all negative effects of a primary matrix. The indicator solution colour change takes place quantitatively and it is constantly monitored by spectrophotometer. The absorbance of a final solution is measured in a $10 \mathrm{~mm}$ glass cell, at $590 \mathrm{~nm}$ wavelength. After detection the solution is directed to the waste reservoir. The analysis of single sample injection takes about two and a half minutes.

\section{Interferences}

Determination of ammonium by flow injection analysis with gaseous diffusion can be affected by volatile amines, too low $\mathrm{pH}$ value or high buffer capacity of the sample, high concentration of salts (more than $10 \mathrm{~g} / \mathrm{dm}^{3}$ ) and high concentration of metal ions like $\mathrm{Cu}^{2+}$, $\mathrm{Zn}^{2+}, \mathrm{Fe}^{3+}, \mathrm{Ca}^{2+}, \mathrm{Mg}^{2+}$ and $\mathrm{Al}^{3+}$. Negative effects mentioned above can be eliminated by sample dilution, and $\mathrm{pH}$ value correction of the sample (by dropwise addition of sodium hydroxide solution). EDTA present in reagent 1 prevents precipitation of metal hydroxides in alkaline conditions during analysis [15].

\section{Results and discussion}

In this work ammonium in water samples from UCG processes was determined by gas-diffusion flow injection analysis and the reliability of the results provided by the applied method was evaluated by checking precision and accuracy. Before each analysis the calibration was carried out. The six-point calibration curve within the range of 0.02-1.0 $\mathrm{mg} \mathrm{NH}_{4}{ }^{+} / \mathrm{dm}^{3}$ was calculated basing on the quadratic equation. Each calibration point was measured three times.

\section{Time storage of preserved samples}

Studies were conducted how the passage of time affects the concentration of ammonium in samples preserved with $\mathrm{H}_{2} \mathrm{SO}_{4}$ (to $\mathrm{pH}$ value below 2). Water samples from different UCG processes were under test. The stability of ammonium concentration in preserved samples was not constant, varied from 1 to 14 days. There were no increasing or decreasing trends of analyte concentration in preserved samples, so in this work each sample was treated as unstable and analysed immediately after collection. 
Determination of ammonium concentration in post-process waters from underground ...

Table 1

Type and origin of raw coal subjected to UCG process and selected physicochemical parameters of waters from different UCG processes

\begin{tabular}{|c|c|c|c|c|c|c|c|c|c|c|c|}
\hline \multicolumn{2}{|c|}{\begin{tabular}{|c|}
$\begin{array}{c}\text { Parameter/ } \\
\text { compound }\end{array}$ \\
\end{tabular}} & $\begin{array}{l}\text { Conduc- } \\
\text { tivity }\end{array}$ & pH & $\mathbf{F e}$ & Zn & $\mathrm{SO}_{4}{ }^{2-}$ & $\mathrm{S}^{2-}$ & COD $^{a}$ & DOC $^{\mathrm{b}}$ & Phenols & $\mathbf{T N}^{\mathbf{c}}$ \\
\hline \multicolumn{2}{|r|}{ Unit } & \multirow[t]{2}{*}{ 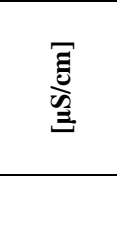 } & \multirow[t]{2}{*}{ - } & \multirow[t]{2}{*}{ 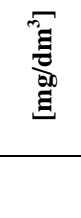 } & \multirow[t]{2}{*}{ 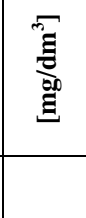 } & \multirow[t]{2}{*}{ 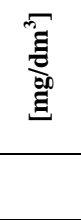 } & \multirow[t]{2}{*}{$\stackrel{\bar{g}}{\underline{\Xi}}$} & \multirow[t]{2}{*}{ 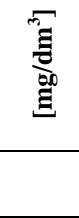 } & \multirow[t]{2}{*}{ 苞 } & \multirow[t]{2}{*}{ 焉 } & \multirow[t]{2}{*}{ 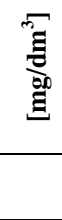 } \\
\hline Sample & $\begin{array}{c}\text { Coal type / } \\
\text { origin of coal }\end{array}$ & & & & & & & & & & \\
\hline A & $\begin{array}{c}\text { Lignite/ } \\
\text { Bełchatow Coal } \\
\text { Mine (PL) }\end{array}$ & 9380 & 1.7 & 855 & 155 & 3620 & 0.54 & 1140 & 382 & 94 & 370 \\
\hline B & \begin{tabular}{|c|} 
Hard coal / \\
Ziemowit Coal Mine \\
$(\mathrm{PL})$
\end{tabular} & 8400 & 2.7 & 530 & 44 & 757 & 1.1 & 11300 & 3000 & 1500 & 900 \\
\hline $\mathrm{C}$ & $\begin{array}{c}\text { Hard coal / } \\
\text { Wieczorek Coal } \\
\text { Mine (PL) }\end{array}$ & 16700 & 8.2 & 0.75 & 0.14 & 122 & 21 & 4740 & 1300 & 1200 & 1800 \\
\hline D & $\begin{array}{c}\text { Hard coal / } \\
\text { Piast Coal Mine (PL) }\end{array}$ & 9570 & 7.9 & 2.64 & 0.14 & 220 & 5.9 & 5130 & 2100 & 900 & 1100 \\
\hline $\mathrm{E}$ & \begin{tabular}{|c} 
Hard coal / \\
Barbara Coal Mine \\
(PL)
\end{tabular} & 10700 & 3.2 & 820 & 3.12 & 5040 & 0.59 & 5360 & 1370 & 570 & 1500 \\
\hline $\mathrm{F}_{12 \mathrm{~h}}$ & \multirow{4}{*}{$\begin{array}{c}\text { Hard coal / } \\
\text { Ziemowit Coal Mine } \\
\text { (PL) }\end{array}$} & 6890 & 2.6 & 361 & 107 & 419 & n.d. $^{\mathrm{d}}$ & 8980 & 1900 & 960 & 510 \\
\hline $\mathrm{F}_{24 \mathrm{~h}}$ & & 7910 & 3.5 & 187 & 17.4 & 183 & n.d. $^{\mathrm{d}}$ & 11400 & 2700 & 1200 & 900 \\
\hline$F_{36 h}$ & & 8090 & 2.2 & 134 & 27.4 & 147 & n.d. ${ }^{d}$ & 9990 & 2400 & 1300 & 660 \\
\hline $\mathrm{F}_{48 \mathrm{~h}}$ & & 10200 & 7.4 & 32.8 & 0.42 & 117 & n.d. $^{\text {d }}$ & 14200 & 3000 & 1100 & 1320 \\
\hline $\mathrm{G}_{24 \mathrm{~h}}$ & \multirow{7}{*}{$\begin{array}{c}\text { Hard coal/ } \\
\text { Staszic-Murcki } \\
\text { Coal Mine (PL) }\end{array}$} & 3480 & 6.6 & 0.09 & 0.01 & 25 & 21 & 2290 & 680 & 340 & 450 \\
\hline $\mathrm{G}_{48 \mathrm{~h}}$ & & 3030 & 6.6 & 0.03 & 0.01 & 28 & 0.48 & 2260 & 690 & 270 & 400 \\
\hline $\mathrm{G}_{72 \mathrm{~h}}$ & & 4060 & 6.6 & 0.01 & 0.01 & 26 & 2.5 & 4900 & 1400 & 780 & 520 \\
\hline $\mathrm{G}_{96 \mathrm{~h}}$ & & 2050 & 6.3 & 0.01 & 0.01 & 27 & $<0.2$ & 2230 & 700 & 290 & 240 \\
\hline $\mathrm{G}_{120 \mathrm{~h}}$ & & 2260 & 6.5 & 0.01 & $<0.01$ & 29 & $<0.2$ & 1610 & 500 & 210 & 270 \\
\hline $\mathrm{G}_{144 \mathrm{~h}}$ & & 1080 & 3.3 & 1.75 & 0.42 & 23 & 2.1 & 208 & 65 & 14 & 70 \\
\hline $\mathrm{G}_{168 \mathrm{~h}}$ & & 8760 & 8.0 & 0.04 & $<0.01$ & 32 & 0.25 & 6530 & 2000 & 970 & 1200 \\
\hline $\mathrm{H}_{24 \mathrm{~h}}$ & \multirow{6}{*}{$\begin{array}{c}\text { Lignite/ } \\
\text { Velenje } \\
\text { Coal Mine (SI) }\end{array}$} & 1060 & 7.0 & 0.01 & 0.08 & 42 & 0.36 & 5320 & 1800 & 300 & 160 \\
\hline $\mathrm{H}_{48 \mathrm{~h}}$ & & 1500 & 7.4 & 0.01 & 0.08 & 32 & 0.38 & 6010 & 2200 & 440 & 250 \\
\hline $\mathrm{H}_{72 \mathrm{~h}}$ & & 2320 & 7.4 & $<0.01$ & 0.05 & 35 & 0.21 & 5060 & 1700 & 390 & 370 \\
\hline $\mathrm{H}_{96 \mathrm{~h}}$ & & 1690 & 7.0 & $<0.01$ & 0.07 & 52 & 0.14 & 4380 & 1300 & 290 & 260 \\
\hline $\mathrm{H}_{120 \mathrm{~h}}$ & & 3140 & 7.4 & 0.01 & 0.02 & 78 & 0.37 & 8740 & 3000 & 660 & 530 \\
\hline $\mathrm{H}_{144 \mathrm{~h}}$ & & 5160 & 7.8 & 0.19 & 0.06 & 35 & 0.63 & 11600 & 4400 & 850 & 910 \\
\hline $\mathrm{I}_{24 \mathrm{~h}}$ & \multirow{4}{*}{$\begin{array}{c}\text { Lignite/ } \\
\text { Velenje } \\
\text { Coal Mine (SI) }\end{array}$} & 267 & 5.9 & 1.35 & 0.01 & 33 & 5.0 & 1320 & 340 & 29 & 13 \\
\hline $\mathrm{I}_{48 \mathrm{~h}}$ & & 5480 & 7.5 & 0.024 & $<0.01$ & 70 & 9.0 & 10400 & 3400 & 620 & 1300 \\
\hline $\mathrm{I}_{72 \mathrm{~h}}$ & & 4450 & 7.5 & 0.038 & $<0.01$ & 39 & 5.7 & 961 & 250 & 68 & 830 \\
\hline $\mathrm{I}_{96 \mathrm{~h}}$ & & 876 & 6.2 & 0.14 & $<0.01$ & 36 & 2.2 & 197 & 36 & 7.0 & 110 \\
\hline $\mathbf{J}_{24 \mathrm{~h}}$ & \multirow{4}{*}{$\begin{array}{l}\text { Lignite/ } \\
\text { Velenje } \\
\text { al Mine (SI) }\end{array}$} & 214 & 7.8 & 2.59 & 0.03 & 35 & 0.71 & 984 & 240 & 21 & 9.7 \\
\hline $\mathrm{J}_{48 \mathrm{~h}}$ & & 5830 & 8.3 & 0.02 & $<0.01$ & 57 & 0.91 & 9060 & 2800 & 710 & 1100 \\
\hline $\mathrm{J}_{72 \mathrm{~h}}$ & & 3010 & 8.1 & 0.06 & 0.01 & 37 & 0.28 & 804 & 220 & 64 & 510 \\
\hline $\mathrm{J}_{96 \mathrm{~h}}$ & & 1230 & 7.9 & 0.12 & 0.01 & 31 & 1.6 & 205 & 60 & 13 & 150 \\
\hline
\end{tabular}




\section{Accuracy}

Due to lack of a certified reference material with matrix similar to water samples from UCG process, accuracy was determined in terms of recovery using multiple standard addition method. Before preparing spiked samples the concentration of ammonium in each raw sample was determined $\left(c_{0}\right)$. Afterwards, the sample with known addition of ammonium standard solution was analysed. Studies of multiple standard addition were carried out at five increasing concentration levels for each sample and each sample with standard addition was measured three times. All of the samples were examined after appropriate dilution with deionised water depending on high ammonium concentration. The recovery studies were carried out and the percentage standard recovery was calculated. The results are presented in Table 2.

Recovery studies of multiple standard addition method

Table 2

\begin{tabular}{|c|c|c|c|c|c|}
\hline \multirow[t]{2}{*}{ Sample } & \multirow{2}{*}{$\begin{array}{c}\text { Aliquot of sample } \\
\text { dilution }\end{array}$} & $\begin{array}{c}\text { Concentration } \\
\text { added }\end{array}$ & $\begin{array}{l}\text { Concentration } \\
\text { found }^{b}\end{array}$ & $\begin{array}{c}\text { Concentration } \\
\text { found }^{\mathrm{c}}\end{array}$ & \multirow{2}{*}{$\begin{array}{c}\text { Recovery } \\
{[\%]}\end{array}$} \\
\hline & & \multicolumn{3}{|c|}{$\left[\mathrm{mg} \mathrm{NH}_{4}{ }^{+} / \mathrm{dm}^{3}\right]$} & \\
\hline \multirow{6}{*}{ A } & \multirow{6}{*}{1500} & $0^{\mathrm{a}}$ & $0.309 \pm 0.001$ & - & - \\
\hline & & 0.1 & $0.418 \pm 0.002$ & 0.109 & 109 \\
\hline & & 0.2 & $0.521 \pm 0.001$ & 0.211 & 106 \\
\hline & & 0.3 & $0.624 \pm 0.001$ & 0.315 & 105 \\
\hline & & 0.4 & $0.725 \pm 0.001$ & 0.416 & 104 \\
\hline & & 0.5 & $0.831 \pm 0.001$ & 0.521 & 104 \\
\hline \multirow{6}{*}{ B } & \multirow{6}{*}{2000} & $0^{\mathrm{a}}$ & $0.127 \pm 0.001$ & - & - \\
\hline & & 0.1 & $0.232 \pm 0.001$ & 0.105 & 105 \\
\hline & & 0.2 & $0.329 \pm 0.001$ & 0.202 & 101 \\
\hline & & 0.3 & $0.430 \pm 0.001$ & 0.303 & 101 \\
\hline & & 0.4 & $0.532 \pm 0.002$ & 0.405 & 101 \\
\hline & & 0.5 & $0.638 \pm 0.001$ & 0.511 & 102 \\
\hline \multirow{6}{*}{$\mathrm{C}$} & \multirow{6}{*}{16000} & $0^{\mathrm{a}}$ & $0.113 \pm 0.003$ & - & - \\
\hline & & 0.1 & $0.210 \pm 0.004$ & 0.087 & 87 \\
\hline & & 0.2 & $0.298 \pm 0.002$ & 0.171 & 86 \\
\hline & & 0.3 & $0.399 \pm 0.003$ & 0.272 & 91 \\
\hline & & 0.4 & $0.499 \pm 0.003$ & 0.372 & 93 \\
\hline & & 0.5 & $0.600 \pm 0.003$ & 0.473 & 95 \\
\hline \multirow{6}{*}{$\mathrm{D}$} & \multirow{6}{*}{4000} & $0^{\mathrm{a}}$ & $0.289 \pm 0.003$ & - & - \\
\hline & & 0.1 & $0.398 \pm 0.004$ & 0.109 & 109 \\
\hline & & 0.2 & $0.503 \pm 0.004$ & 0.214 & 107 \\
\hline & & 0.3 & $0.608 \pm 0.001$ & 0.319 & 106 \\
\hline & & 0.4 & $0.710 \pm 0.001$ & 0.421 & 105 \\
\hline & & 0.5 & $0.818 \pm 0.005$ & 0.529 & 106 \\
\hline \multirow{6}{*}{$\mathrm{E}$} & \multirow{6}{*}{8000} & $0^{\mathrm{a}}$ & $0.247 \pm 0.004$ & - & - \\
\hline & & 0.1 & $0.349 \pm 0.001$ & 0.102 & 102 \\
\hline & & 0.2 & $0.456 \pm 0.001$ & 0.209 & 104 \\
\hline & & 0.3 & $0.569 \pm 0.002$ & 0.321 & 107 \\
\hline & & 0.4 & $0.681 \pm 0.002$ & 0.434 & 108 \\
\hline & & 0.5 & $0.789 \pm 0.003$ & 0.542 & 108 \\
\hline
\end{tabular}

${ }^{\text {a }}$ Concentration of ammonium in diluted sample before standard addition $\left(c_{0}\right)$

${ }^{\mathrm{b}}$ Mean value and standard deviation of three determinations

${ }^{\mathrm{c}}$ Concentration of ammonium in spiked samples corrected of $c_{0}$ 
Additionally, the relationships between $c_{F o u n d}$ (where $c_{F o u n d}$ ' was a concentration of ammonium in spiked sample corrected of $c_{0}$ determined in diluted sample) and corresponding concentrations of ammonium standard addition are shown in Table 3.

Table 3

Linear regression parameters in multiple standard addition method

\begin{tabular}{|c|c|c|c|}
\hline \multirow{2}{*}{ Sample } & \multicolumn{3}{|c|}{$\boldsymbol{y}=\boldsymbol{a x}+\boldsymbol{b}$} \\
\cline { 2 - 4 } & Slope $\boldsymbol{a}$ & Intercept $\boldsymbol{b}$ & ${\text { Coefficient of determination } \boldsymbol{R}^{\mathbf{2}}}^{*}$ \\
\hline A & 1.03 & 0.006 & 0.9999 \\
\hline B & 1.01 & 0.001 & 0.9997 \\
\hline C & 0.97 & 0.016 & 0.9976 \\
\hline D & 1.05 & 0.004 & 0.9996 \\
\hline E & 1.10 & 0.010 & 0.9998 \\
\hline
\end{tabular}

The exemplary graphical relationships are presented for sample A in Figure 2. What is more, the Cochran's test was applied to verify whether the concentration level affects the variability of the results. The values of Cochran test parameter $\left(C_{\text {exp }}\right)$ amounted 0.333 ; $0.619 ; 0.428 ; 0.484$ and 0.488 for samples A, B,C, D and E respectively. $C_{\text {exp }}$ was lower than $C_{t a b}=0.707(\alpha=0.05 ; p=5 ; n=3)$ in each case.

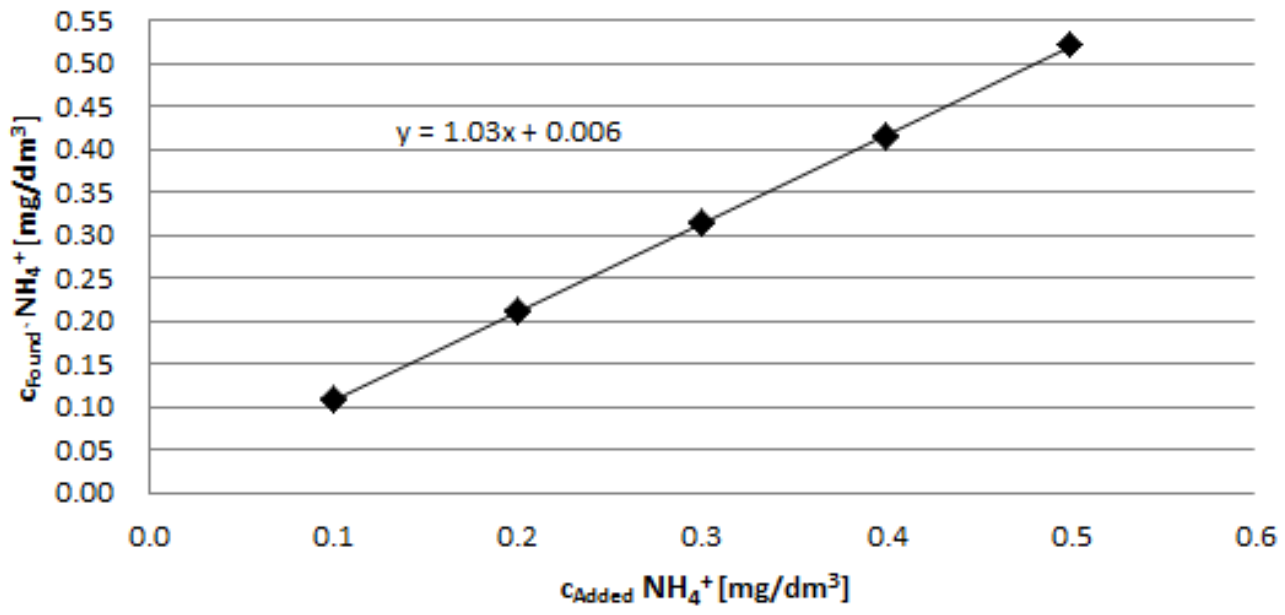

Fig. 2. Determination of ammonium in water from UCG process using multiple standard addition method. Sample A

\section{Precision}

In this work the precision was studied as interlaboratory repeatability and expressed as the percentage coefficients of variation $(\mathrm{CV})$. Each water sample from UCG was diluted with deionised water to three or two different levels (samples A-E; series of samples F-J, respectively) and after that ammonium was determined in all samples. The CV was evaluated for each sample basing on two or three obtained results $(n)$. The results are shown in Table 4. 
Results of precision under repeatability conditions

\begin{tabular}{|c|c|c|c|c|}
\hline Sample & $\begin{array}{c}\text { Concentration found } \mathrm{NH}_{4}{ }^{+\mathrm{a}} \\
{\left[\mathrm{mg} / \mathrm{dm}^{3}\right]}\end{array}$ & $\begin{array}{l}\text { Concentration found } \mathrm{N}^{-\mathrm{NH}_{4}}{ }^{+\mathrm{b}} \\
{\left[\mathrm{mg} / \mathrm{dm}^{3}\right]}\end{array}$ & $\begin{array}{c}C V \\
{[\%]}\end{array}$ & $n_{i}$ \\
\hline A & $440 \pm 20$ & 342 & 4.5 & 3 \\
\hline B & $258 \pm 6$ & 200 & 2.3 & 3 \\
\hline $\mathrm{C}$ & $1900 \pm 80$ & 1475 & 4.2 & 3 \\
\hline $\mathrm{D}$ & $1160 \pm 40$ & 901 & 3.4 & 3 \\
\hline $\mathrm{E}$ & $1930 \pm 50$ & 1499 & 2.6 & 3 \\
\hline $\mathrm{F}_{12 \mathrm{~h}}$ & $556 \pm 47$ & 432 & 8.4 & 2 \\
\hline $\mathrm{F}_{24 \mathrm{~h}}$ & $985 \pm 32$ & 765 & 3.2 & 2 \\
\hline $\mathrm{F}_{36 \mathrm{~h}}$ & $665 \pm 37$ & 516 & 5.6 & 2 \\
\hline $\mathrm{F}_{48 \mathrm{~h}}$ & $1590 \pm 60$ & 1235 & 3.8 & 2 \\
\hline $\mathrm{G}_{24 \mathrm{~h}}$ & $511 \pm 6$ & 397 & 1.2 & 2 \\
\hline $\mathrm{G}_{48 \mathrm{~h}}$ & $496 \pm 4$ & 385 & 0.9 & 2 \\
\hline $\mathbf{G}_{72 \mathrm{~h}}$ & $660 \pm 41$ & 512 & 6.2 & 2 \\
\hline $\mathrm{G}_{96 \mathrm{~h}}$ & $295 \pm 9$ & 229 & 3.0 & 2 \\
\hline $\mathrm{G}_{120 \mathrm{~h}}$ & $340 \pm 18$ & 264 & 5.3 & 2 \\
\hline $\mathrm{G}_{144 \mathrm{~h}}$ & $87 \pm 4$ & 68 & 4.6 & 2 \\
\hline $\mathrm{G}_{168 \mathrm{~h}}$ & $1460 \pm 20$ & 1134 & 1.4 & 2 \\
\hline $\mathrm{H}_{24 \mathrm{~h}}$ & $158 \pm 4$ & 123 & 2.2 & 2 \\
\hline $\mathrm{H}_{48 \mathrm{~h}}$ & $278 \pm 3$ & 216 & 0.9 & 2 \\
\hline $\mathrm{H}_{72 \mathrm{~h}}$ & $423 \pm 3$ & 328 & 0.8 & 2 \\
\hline $\mathrm{H}_{96 \mathrm{~h}}$ & $313 \pm 2$ & 243 & 0.7 & 2 \\
\hline $\mathrm{H}_{120 \mathrm{~h}}$ & $628 \pm 9$ & 488 & 1.4 & 2 \\
\hline $\mathrm{H}_{144 \mathrm{~h}}$ & $1140 \pm 40$ & 885 & 3.5 & 2 \\
\hline $\mathrm{I}_{24 \mathrm{~h}}$ & $5.13 \pm 0.18$ & 3.98 & 3.5 & 2 \\
\hline $\mathrm{I}_{48 \mathrm{~h}}$ & $1150 \pm 50$ & 893 & 4.4 & 2 \\
\hline $\mathrm{I}_{72 \mathrm{~h}}$ & $888 \pm 43$ & 690 & 4.8 & 2 \\
\hline$I_{96 \mathrm{~h}}$ & $121 \pm 1$ & 94 & 1.1 & 2 \\
\hline$J_{24 h}$ & $8.16 \pm 0.76$ & 6.34 & 9.3 & 2 \\
\hline $\mathrm{J}_{48 \mathrm{~h}}$ & $1310 \pm 30$ & 1017 & 2.3 & 2 \\
\hline $\mathrm{J}_{72 \mathrm{~h}}$ & $646 \pm 62$ & 502 & 9.5 & 2 \\
\hline$J_{96 h}$ & $176 \pm 3$ & 137 & 1.6 & 2 \\
\hline
\end{tabular}

${ }^{a}$ Mean value and standard deviation of three or two determinations

${ }^{\mathrm{b}}$ Conversion factor from concentration $\mathrm{NH}_{4}$ to $\mathrm{N}-\mathrm{NH}_{4}$ : 0.7765

\section{Conclusions}

Determination of ammonium in waters produced during underground gasification of hard coal or lignite by flow injection analysis with gas-diffusion and with spectrophotometric detection was presented. Evaluated accuracy of method was satisfying. The recovery values varied in the range from 86 to 109\%. Standard addition graphs were linear in all cases (coefficient of determination $R^{2}$ was not lower than 0.998 for each sample), the slope of regression was close to one and the intercept was close to zero. The values of Cochran test parameter $\left(C_{e x p}\right)$ were lower than $\left(C_{t a b}\right)$ in all cases that indicated variance equality between all five concentration level groups. Moreover, presented results showed good precision of the FIA-GD method. Precision as interlaboratory repeatability was expressed as the percentage coefficients of variation $(\mathrm{CV})$ obtained for each sample. Obtained $C V$ values ranged from $0.7 \%(n=2)$ to $9.5 \%(n=2)$. All water samples from UCG processes contained high concentrations of ammonium (from 5.13 up to $1930 \mathrm{mg} / \mathrm{dm}^{3}$ ). The determination of ammonium is very important from the environmental 
point of view, because of its toxicity to fish and other aquatic organisms. Ammonia has an adverse effect on the oxygen balance in the aquatic environment and it is classified as a substance which have a deleterious effect on the aquatic environment according to List II of Directive 2006/11/EC of the European Parliament and of the Council of 15 February, 2006 [16]. In Poland Regulation of the Minister of the Environment of 18th November

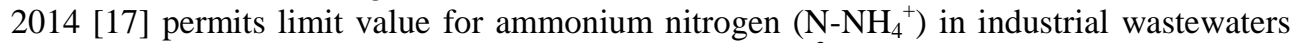
discharged into the ground or surface water as $10 \mathrm{mg} / \mathrm{dm}^{3}$. Almost $94 \%$ of obtained results significantly exceed limit value. In most cases, ammonium nitrogen consists in $80 \%$ of total nitrogen. Presented results clearly demonstrate usefulness of FIA-GD method for routine determination of ammonium in water samples from UCG process, even in samples with high concentration of organic and inorganic compounds (e.g. $1500 \mathrm{mg} / \mathrm{dm}^{3}$ of phenols, $4400 \mathrm{mg} / \mathrm{dm}^{3}$ dissolved organic carbon and $5000 \mathrm{mg} / \mathrm{dm}^{3}$ of sulphate). Further, short time of analysis (150 s), low reagent consumption, small sample volume, possibility of elimination of the matrix effect, good repeatability are the undoubted advantage of the proposed method. The advantages mentioned above allow the flow injection analysis monitoring of ammonium in samples with very difficult matrix, like post-process waters from underground coal gasification.

\section{References}

[1] National Research Council. Coal: Energy for the Future. Washington, DC: The National Academies Press; 1995; 85-112. DOI: 10.17226/4918.

[2] Kapusta K, Stańczyk K. Fuel. 2011;90:1927-1934. DOI: 10.1016/j.fuel.2010.11.025.

[3] Stańczyk K, Howaniec N, Smoliński A, Świądrowski J, Kapusta K, Wiatowski M, et al. Fuel. 2011;90:1953-1962. DOI: 10.1016/j.fuel.2010.12.007.

[4] Minchener AJ. Fuel. 2005;84:2222-2235. DOI: 10.1016/j.fuel.2005.08.035.

[5] Campbell JH, Wang FT, Mead SW, Busby JF. J Hydrol. 1979;44:214-266. DOI: 10.1016/0022-1694(79)90134-3

[6] Oliviera SM, Lopes TIMS, Toth IV, Rangel AOSS. Anal Chim Acta. 2007;600:29-34. DOI: 10.1016/j.aca.2007.01.019.

[7] Andrew KN, Worsfold PJ, Comber M. Anal Chim Acta. 1995;314:33-43. DOI: 10.1016/0003-2670(95)00269-6.

[8] Tovar A, Moreno C, Mánuel-Vez MP, Garcia-Vargas M. Anal Chim Acta. 2002;469:235-242. DOI: 10.1016/S0003-2670(02)00752-3.

[9] Braz HL, Ito DT, Fracassi da Silva JA, do Lago CL, Pedrotti JJ. Electroanalysis. 2011;23:2594-2600. DOI: 10.1002/elan.201100317.

[10] Liu R, Sun B, Liu D, Sun A. Talanta. 1996; 43:1049-1054. DOI: 10.1016/0039-9140(96)01858-9.

[11] Qin W, Zhang Z, Li B, Peng Y. Talanta. 1999; 48:225-229. DOI: 10.1016/S0039-9140(98)00246-X.

[12] Shen H, Cardwell TJ, Cattrall RW. Anal Chim Acta. 1998;367:193-199. DOI: 10.1016/S0003-2670(98)00168-8.

[13] Meseguer-Lloret S, Molins-Legua C, Campins-Falco P. Anal Chim Acta. 2005;536:121-127. DOI: 10.1016/j.aca.2004.12.073.

[14] Haghighi B, Kurd SF. Talanta. 2004;64:688-694. DOI: 10.1016/j.talanta.2004.03.037.

[15] International Organization for Standardization. ISO 11732. www.hsevi.ir/RI_Standard/File/1025.

[16] Directive 2006/11/EC of the European Parliament and of the Council on pollution caused by certain dangerous substances discharged into the aquatic environment of the Community (Codified version); OJ L 64, 04.03.2006, p. 52. www.eur-lex.europa.eu/legal-content/EN/TXT/PDF/?uri=CELEX: 32006L0011\&from=EN.

[17] Rozporządzenie Ministra Środowiska z dnia 18 listopada 2014 r. w sprawie warunków, jakie należy spełnić przy wprowadzaniu ścieków do wód lub do ziemi, oraz w sprawie substancji szczególnie szkodliwych dla środowiska wodnego. DzU 2014, poz. 1800 (Regulation of the Minister of the Environment of 18th November 2014 on the conditions to be met when discharging sewage into water or soil and on substances particularly harmful to the aquatic environment. Journal of laws of 2014.1800. Poland). www.isap.sejm.gov.p1/DetailsServlet?id=WDU20140001800. 


\title{
OZNACZANIE JONÓW AMONU W WODACH Z PROCESU PODZIEMNEGO ZGAZOWANIA WEGLA
}

Główny Instytut Górnictwa (GIG), Katowice

\begin{abstract}
Abstrakt: W artykule przedstawiono możliwość zastosowania wstrzykowej analizy przepływowej z dyfuzją gazową i detekcją spektrofotometryczną do oznaczania stężenia jonów amonu w próbkach wód pochodzących z procesów podziemnego zgazowania węgla kamiennego i brunatnego. Wspomniane powyżej próbki są barwne oraz charakteryzują się skomplikowaną matrycą, co sprawia, że ich analiza należy do bardzo trudnych. Zastosowana metoda polega na przekształceniu pod wpływem silnie alkalicznego środowiska zawartych w próbce jonów amonowych w postać gazowego amoniaku, który, dyfundując następnie przez hydrofobową membranę dyfuzora gazowego, absorbowany jest w roztworze wskaźnika. Absorbcja amoniaku powoduje zmianę odczynu pH roztworu wskaźnika, a tym samym zmianę jego barwy, która rejestrowana jest w sposób ciągły w fotometrze przepływowym przy długości fali świetlnej $590 \mathrm{~nm}$. Na podstawie wyników przeprowadzonych badań określono wartości poprawności oraz precyzji. Poprawność została określona na podstawie wyników badania odzysku (metodą wielokrotnego dodatku wzorca). Precyzję w warunkach powtarzalności wyrażono jako wartość współczynnika zmienności CV.
\end{abstract}

Słowa kluczowe: jony amonu, wstrzykowa analiza przepływowa, dyfuzja gazowa, zgazowanie węgla, wody z podziemnego zgazowania węgla 